\section{Fertilization of 'Angelika Red' Poinsettia using Commercially Prepared Formulations}

\section{M.L. Albrecht, J.T. Lehmann, and D.M. Crockett \\ Department of Horticulture and Forestry, Kansas State University, Manhattan, KS 66506-4002}

Additional index words. Euphorbia pulcherrima

Nitrogen deficiency has been seen on 'Gutbier V-17 Angelika Red' poinsettias (Euphorbia pulcherrima Willd. ex Kl.) portions of the midwestem United States. Poinsettia growth is inferior under an $\mathrm{NH}$,rich regime in comparison to a $\mathrm{NO}$,-program (Lawton et al., 1989). The objective of this study was to determine appropriate production and finishing fertilization programs using commercially available fertilizers to produce quality 'Angelika Red' poinsettias.

Rooted cuttings of 'Angelika Red' were potted on 31 Aug. and grown in 1.7-liter azalea pots filled with either a soilless growing medium (Metro-Mix 510, Grace-Sierra, Milpitas, Calif.) or a soil-based medium [1 soil : 3 sphagnum peat : 3 perlite $(\mathrm{v} / \mathrm{v})$ amended with dolomitic lime at $\left.3 \mathrm{~kg} \cdot \mathrm{m}^{-3}\right]$. Plants were divided into three groups to receive $300 \mathrm{mg} \mathrm{N} /$ liter at each irrigation from three production fertilizers (PROD): $15 \mathrm{~N}$ $7 \mathrm{P}-14 \mathrm{~K} \quad\left(53 \% \quad \mathrm{NO}_{3}-\mathrm{N}, 22 \% \quad \mathrm{NH}_{4},-\mathrm{N}, 25 \%\right.$ urea-N) or $20 \mathrm{~N}-4 \mathrm{P}-17 \mathrm{~K}\left(60 \% \mathrm{NO}_{3}-\mathrm{N}, 40 \%\right.$ $\left.\mathrm{NH}_{4}-\mathrm{N}\right)$ Peter's Peat-Lite Specials, or $20 \mathrm{~N}-$ $9 \mathrm{P}-17 \mathrm{~K}\left(28 \% \quad \mathrm{NO}_{3}-\mathrm{N}, 20 \% \mathrm{NH}_{4}-\mathrm{N}, 52 \%\right.$ urea-N) Peter's General Purpose (GraceSierra, Fogelsville, Pa.).

The finishing program was initiated on 20 Nov. while the inflorescences were completing bract expansion. Half of the plants grown in each medium and under each PROD program were either irrigated with tap water only or with Peter's Poinsettia Finisher $15 \mathrm{~N}$ 9P-21K (47\% $\mathrm{NO}_{3}-\mathrm{N}, 27 \% \quad \mathrm{NH}_{4}-\mathrm{N}, 26 \%$ urea-N) at $300 \mathrm{mg} \mathrm{N} /$ liter at each irrigation.

Commercial poinsettia production procedures were followed with regard to pinching and pest control (Ecke and Matkin, 1976). Plants were grown at 26/18C (day/night) under natural daylengths until 3 Oct., then short days were maintained using black cloth. Night temperature was reduced to $16 \mathrm{C}$. No growthregulating chemicals were used.

The experiment was arranged as a $2 \times 3$ x 2 factorial in a completely randomized design using three replications per factor combination with three single plants per rep-

Received for publication 28 Feb. 1991. Accepted for publication 6 Aug. 1991. Contribution no. 90578-J of the Kansas Agricultural Experiment Station, Kansas State Univ., Manhattan, KS 665064002. The cost of publishing this paper was defrayed in part by the payment of page charges. Under postal regulations, this paper therefore must be hereby marked advertisement solely to indicate this fact. lication. Data were collected when the plants were marketable. Inflorescence diameter was inmeasured across the widest part of the bract display of the upper two lateral branches. Plant parts were separated for drying at $65 \mathrm{C}$. Foliar $\mathrm{N}$ was determined by micro-Kjeldahl (Soil and Plant Tissue Laboratory, Dept. of Agronomy, Kansas State Univ.). The 20N$9 \mathrm{P}-17 \mathrm{~K} /$ water program was considered the control; it was under these conditions that $\mathrm{N}$-deficiency symptoms occurred.

Growing medium had no effect on the attributes measured. Data in Table 1 are means pooled over medium.

Plants produced with $20 \mathrm{~N}-9 \mathrm{P}-17 \mathrm{~K}$ had reduced stem dry weight in comparison with plants on the 20N-4P-17K PROD (6.7 g, $7.3 \mathrm{~g}$, and $5.8 \mathrm{~g}$ for $15 \mathrm{~N}-7 \mathrm{P}-14 \mathrm{~K}, 20 \mathrm{~N}-4 \mathrm{P}-$ $17 \mathrm{~K}$, and $20 \mathrm{~N}-9 \mathrm{P}-17 \mathrm{~K}$ PROD programs, respectively, $\mathrm{LSD}_{0.01}=1.1 \mathrm{~g}$ ).

All programs produced plants that had acceptable foliar-N levels (Cox and Seeley, 1983, 1984), and none produced visual symptoms of $\mathrm{N}$ deficiency. Under the $15 \mathrm{~N}$ $7 \mathrm{P}-14 \mathrm{~K} /$ water program, plants had reduced dry weights, yet bract size and total foliar $\mathrm{N}$ were not affected in comparison to other programs. Bract dry weight was highest for plants in the $20 \mathrm{~N}-4 \mathrm{P}-17 \mathrm{~K} /$ water program. The plants under the $15 \mathrm{~N}-7 \mathrm{P}-14 \mathrm{~K} / 15 \mathrm{~N}-9 \mathrm{P}-21 \mathrm{~K}$ program had the lowest foliar- $\mathrm{N}$ levels and the highest total plant dry weight. Inflorescence diameter was smallest for plants in the $20 \mathrm{~N}-9 \mathrm{P}-17 \mathrm{~K} /$ water program, yet bract size for plants in the $20 \mathrm{~N}-9 \mathrm{P}-17 \mathrm{~K} / 15 \mathrm{~N}-9 \mathrm{P}-21 \mathrm{~K}$ program did not differ from other PROD programs. The proportion of $\mathrm{NO}_{3}-\mathrm{N}(47 \%)$ in $15 \mathrm{~N}-9 \mathrm{P}-21 \mathrm{~K}$ may have aided final bract enlargement. This effect was not seen with the other two PROD programs, possibly due to adequate $\mathrm{NO}_{3}-\mathrm{N}$ levels available throughout crop development. This contrasts with Lawton et al. (1989) who produced poinsettias using only $15 \mathrm{~N}-7 \mathrm{P}-14 \mathrm{~K}$, which has slightly more available $\mathrm{N}$ in the $\mathrm{NO}$,-form than $15 \mathrm{~N}-9 \mathrm{P}-21 \mathrm{~K}$.

Because 1) there were no visual N-deficiency symptoms, 2) inflorescences were of desirable size, 3) total plant dry weight was satisfactory, and 4) foliar-N levels were within acceptable levels, the $15 \mathrm{~N}-7 \mathrm{P}-14 \mathrm{~K} / 15 \mathrm{~N}-9 \mathrm{P}-$ $21 \mathrm{~K}$ and the $20 \mathrm{~N}-4 \mathrm{P}-17 \mathrm{~K} /$ water programs or similar fertilizers are recommended for

\section{Literature Cited}

Cox, D.A. and J.G. Seeley. 1983. The effect of nitrogen and potassium fertilization and sample date on the macronutrient composition of poinsettia leaves. HortScience 18(5):751-752.

Cox, D.A. and J.G: Seeley. 1984. Ammonium injury to poinsettia: Effects of $\mathrm{NH}_{4}-\mathrm{N}: \mathrm{NO}_{3}-\mathrm{N}$ ratio and $\mathrm{pH}$ control in solution culture on growth, $\mathrm{N}$ absorption, and $\mathrm{N}$ utilization. J. Amer. Soc. Hort. Sci. 109(1):57-62.

Ecke, P., Jr. and O.A. Matkin. 1976. The poinsettia manual. 2nd ed. Paul Ecke Poinsettias, Encinitas, Calif.

Lawton, K.A., G.L. McDaniel, and E.T. Graham. 1989, Nitrogen source and calcium supplement affect stem strength of poinsettia. HortScience 24(3):463-465. 'Angelika Red' poinsettias.

Table 1. Dry weights, inflorescence diameters, and total foliar $\mathrm{N}$ as influenced by production fertilizer and finishing program for 'Angelika Red' poinsettia.

\begin{tabular}{|c|c|c|c|c|}
\hline \multirow{2}{*}{$\begin{array}{l}\text { Growth } \\
\text { measurement }\end{array}$} & \multirow{2}{*}{$\begin{array}{l}\text { Finishing } \\
\text { program }\end{array}$} & \multicolumn{3}{|c|}{ Production fertilizer } \\
\hline & & $15 \mathrm{~N}-7 \mathrm{P}-14 \mathrm{~K}$ & $20 \mathrm{~N}-4 \mathrm{P}-17 \mathrm{~K}$ & $20 \mathrm{~N}-9 \mathrm{P}-17 \mathrm{~K}$ \\
\hline \multicolumn{5}{|l|}{$\overline{\text { Dry wt }(\mathrm{g})}$} \\
\hline Stem & $\begin{array}{c}\text { Water } \\
15 \mathrm{~N}-9 \mathrm{P}-21 \mathrm{~K}\end{array}$ & $\begin{array}{l}6.2 \\
7.1\end{array}$ & $\begin{array}{l}7.7 \\
6.9\end{array}$ & $\begin{array}{l}6.0 \\
5.5\end{array}$ \\
\hline \multicolumn{5}{|l|}{ LSD NS } \\
\hline Leaves & $\begin{array}{c}\text { Water } \\
15 \mathrm{~N}-9 \mathrm{P}-21 \mathrm{~K}\end{array}$ & $\begin{array}{l}6.3 \\
9.3\end{array}$ & $\begin{array}{l}7.3 \\
6.5\end{array}$ & $\begin{array}{l}7.9 \\
6.5\end{array}$ \\
\hline \multicolumn{5}{|l|}{$\mathrm{LSD}_{0.05} 2.8$} \\
\hline Bracts & $\begin{array}{c}\text { Water } \\
15 \mathrm{~N}-9 \mathrm{P}-21 \mathrm{~K}\end{array}$ & $\begin{array}{l}8.2 \\
9.4\end{array}$ & $\begin{array}{r}10.3 \\
8.9\end{array}$ & $\begin{array}{l}8.4 \\
9.1\end{array}$ \\
\hline \multicolumn{5}{|l|}{$\mathrm{LSD}_{0.01} 1.6$} \\
\hline Total & $\begin{array}{c}\text { Water } \\
15 \mathrm{~N}-9 \mathrm{P}-21 \mathrm{~K}\end{array}$ & $\begin{array}{l}20.7 \\
25.9\end{array}$ & $\begin{array}{l}25.2 \\
22.2\end{array}$ & $\begin{array}{l}22.3 \\
21.1\end{array}$ \\
\hline \multicolumn{5}{|c|}{$\begin{array}{l}L_{S D_{0.0 s}} 3.8 \\
\text { Inflorescence diam }(\mathrm{cm})\end{array}$} \\
\hline First & $\begin{array}{c}\text { Water } \\
15 \mathrm{~N}-9 \mathrm{P}-21 \mathrm{~K}\end{array}$ & $\begin{array}{l}34.3 \\
34.3\end{array}$ & $\begin{array}{l}34.5 \\
34.9\end{array}$ & $\begin{array}{l}32.3 \\
34.8\end{array}$ \\
\hline $\begin{array}{l}\mathrm{LSD}_{0.05} 1.5 \\
\text { Second }\end{array}$ & $\begin{array}{c}\text { Water } \\
15 \mathrm{~N}-9 \mathrm{P}-21 \mathrm{~K}\end{array}$ & $\begin{array}{l}34.1 \\
34.5\end{array}$ & $\begin{array}{l}34.5 \\
34.3\end{array}$ & $\begin{array}{l}31.4 \\
35.1\end{array}$ \\
\hline $\begin{array}{l}\operatorname{LSD}_{0.05} 2.2 \\
\text { Total foliar } \mathrm{N} \\
(\%) \\
\quad \operatorname{LSD}_{0.01} 0.46\end{array}$ & $\begin{array}{c}\text { Watcr } \\
15 \mathrm{~N}-9 \mathrm{P}-21 \mathrm{~K}\end{array}$ & $\begin{array}{l}4.01 \\
3.48\end{array}$ & $\begin{array}{l}3.61 \\
3.81\end{array}$ & $\begin{array}{l}4.01 \\
4.08\end{array}$ \\
\hline
\end{tabular}

NSProduction fertilizer $\times$ finishing treatment interaction not significant for this measurement. 